\section{Cartographic Sublime}

Frances Hsu

University of North Carolina Charlotte
Kant distinguishes two notions of the sublime: the mathematically sublime and the dynamically sublime. In the case of both notions, the experience of the sublime consists in a feeling of the superiority of our own power of reason, as a supersensible faculty, over nature. (Stanford Encyclopedia of Philosophy) ${ }^{1}$

The concept of the sublime was associated with nature in late 18th and early 19th century aesthetics. Political philosopher and statesman Edmund Burke evoked human mortality in A Philosophical Inquiry into the Origin of our Ideas of the Sublime and the Beautiful, defining the sublime as experience of the overwhelming magnitude of phenomena in the natural world which causes "a sort of delightful horror, a sort of tranquility tinged with terror; which, as it belongs to self-preservation, is one of the strongest of all the passions." ${ }^{2}$ Kant, in contrast to Burke, defines rationality is an important component of the experience of the sublime: "The sublime is to be found in an object even devoid of form, so far as it immediately involves, or else by its presence provokes a representation of limitlessness, yet with a super-added thought of its totality." ${ }^{3}$ That is, reason--super-added thought--allows us to comprehend and challenge the entirety of that which is beyond comprehension. He writes that "the feeling of the sublime in nature is respect for our own vocation ... this feeling renders as it were intuitable the supremacy of our cognitive faculties on the rational side over the greatest faculty of sensibility." 4 For Kant, in other words, the experience of the sublime was the oscillation between sensation and rationality in the face of the overwhelmingness of phenomena in the world.

In architecture, the interaction of the natural world with the built environment is a particular problem in the design of cities and current debates on urbanization. Complex anthropogenetic transformations of nature (e.g., deforestation, pollution), capital and labor (e.g., industrialized agriculture, big data) have been addressed by a range of teaching and design practices. These practices have taken up methods of cartographical representation not only to challenge the conventions of urban design and planning but also to point to a crisis in the totalizing notions of the master plan and the grand narratives depicted in the history of cities. The study and representation of metabolisms, network flows, infrastructures, polymorphous conditions and self-organizing fluidities in diagrams, maps and plans has been viewed as progressive, belying not only more traditional focus on meaning and significance in the built environment but also the common understanding of the purpose of architectural training in modern Western societies in which students acquired knowledge and understanding of pre-existing entities, events and practices. Mapping technologies are seminal to the conceptualization and engagement of the urban as transdisciplinary and systemic, and as such became the new design paradigm for *swerving* away from the classical tectonic and compositional themes in architectural education.

Maps challenge the static conventions of architectural drawing and open possibilities for temporal, localized understandings of knowledge in relationship to physical space. The activity of map-making 


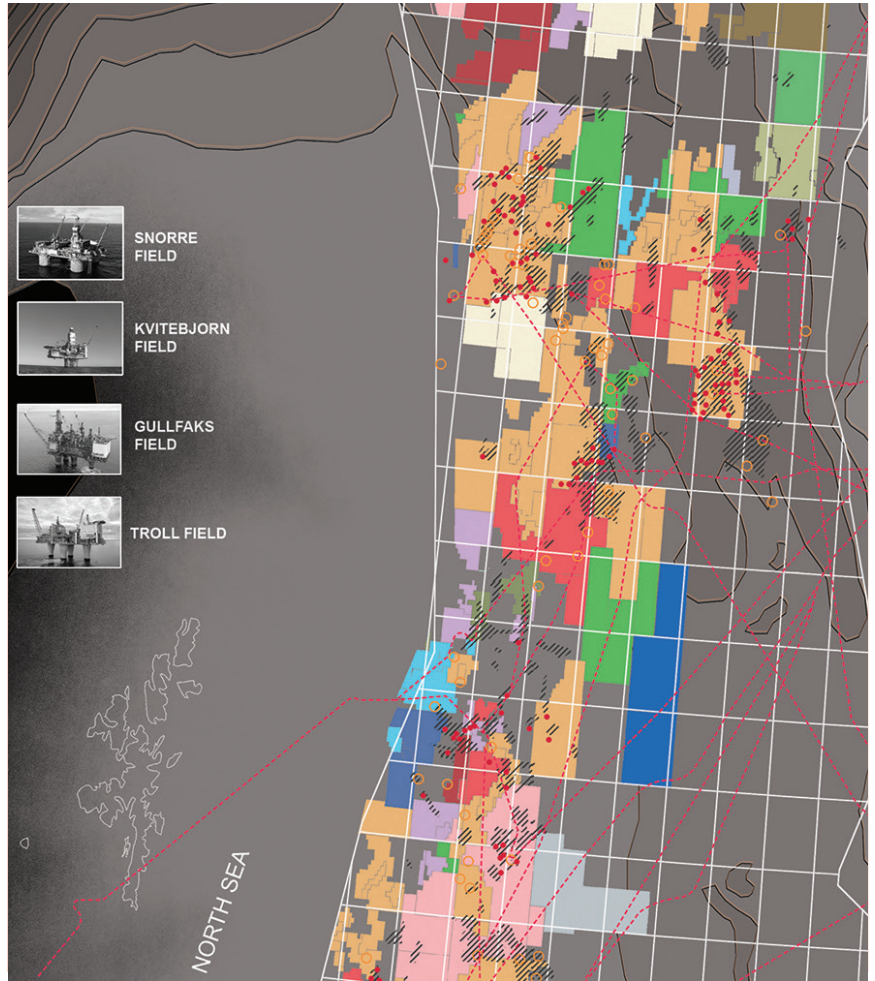

Figure 1. Urbanization of the Norwegian Sea showing ownership of oil field. (Studio Hsu, Aalto University Student Stefanos Theodorou)

may be both analytical and expressive, a critical as well as interpretive tool for speculating upon processes of change linking research and design exploration. Maps may convey ideas and be deployed to provide a narrative dimension to information and data and to articulate ideas about place and space at the scales ranging from the body to the region to the globe. (Design Earth/El Hadi Jazairy Rania Ghosn/ MIT) Modes of mapping, conceived as essential to design, may function less as an accurate description or illustration of territory and more as an entry into the possibilities and prejudices that inhabit a certain place at a certain time. (Spin Unit/Damiano Cerrone et alia/Tampere University of Technology, Finland)

Contemporary architecture's pedagogical practice of mapping is driven by practices and teaching that use representational tools of map-making to chart/reveal the complex and fragmented processes and forces of urbanization. Maps are used to conceptualize territories as sets and series of different relational systems characterized by feedback loops and interactions with regional and global impacts (Many Norths: Spatial Practice in a Polar Territory, Lola Sheppard, Mason White, Lateral Office, 2017) Pedagogies may be projective (Open Workshop/Neeraj Bhati/CCA; Future Cities Lab/ETHZ; Landscape Infrastructure Lab/Pierre Bélanger/Harvard GSD). In deploying the methods of cartography for the evaluation of forms, objects, networks, and actions, they may be critical (Center for Spatial Research/ Laura Kurgan/Columbia GSAPP; Forensic Architecture/ Eyal Weizman/Goldsmiths University of London), thus fulfilling the call for use of innovations in mapping and information visualization in multi-disciplinary collaboration to demonstrate designers' engagement with "real world of market democracy and global forces" and the "critical and creative capacity to realign those conditions toward more socially enriching ends." ${ }^{5}$

\section{ARCHITECTURAL DESIGN PEDAGOGIES}

The obsession with mapping can be situated in the discipline as part of competing foci on figure vs. field. On the one hand, a re-grounding of the discipline is suggested by the publications Possible Mediums and Call to Order produced by professors at the schools of architecture at Ohio State University, Syracuse University, University of Illinois at Chicago, University of Michigan, and University of Miami. New formal explorations using the potentials of new technologies of construction, materials and manufacturing demonstrate a renewed interest in traditional values of simplicity, precedent, history, and typology. On the other hand, a narrative of extended and globally pervasive urban growth presented by Implosions/Explosions: Towards a Study of Planetary Urbanization (Brenner 2014) interrogates the environment of territories outside of the conventionally described city limits.

The dichotomy of figure and field originates in the provocations of the post-critical in Perspecta/Yale Architecture Journal and the responses by Reinhold Martin in Harvard Design Magazine and Log. 6 Post-criticality was conceived as "an alternative to the now dominant paradigm of criticality" that would focus on the traditional architect's professional task of buildings. Martin criticized the implicit call for architects to accept their participation in the allegedly inevitable procedures of global capital at work in the urban realm. He characterized post-critical practices as "sharing a commitment to an affect-driven, non-oppositional, nonresistance, nondissenting, and therefore nonutopian, forms of architectural production." Such practice "usually winds up testifying not to the existence of a critical architecture, but to its impossibility, or at most, its irreducible negativity in the face of the insurmountable violence perpetrated by ... 'late capitalism.'"'7

The mapping of urbanized present and futures is linked to German geographer Walter Christaller, who explained the spatial arrangements and distribution of settlements and their number based on population and distance from other settlements. His theory was based on the study of settlement patterns in southern Germany and included the mathematical analysis of relationships between settlements of different sizes and related their economic activities with population. It is in this sense that mapping is part of a broad inquiry on the influence of empirical approaches of 20th century sciences, such as geography, on the practice and teaching of design. In his Central Place Theory, Christaller identifies the polarities of global and local:

"Freedom to move, a scarce and unequally distributed commodity, quickly becomes the main stratifying factor of our times... A particular cause for worry is the progressive breakdown in communication between the increasingly global and extraterritorial elites and the ever more 'localized' rest." ${ }^{8}$ 
The mid-century search in the field of urban geography for a general systems theory of urbanization following up on Christaller's efforts to understand how cities and groups of cities developed as they did was critiqued by David Harvey, who in the 1970s identified in the geographies and policies supported by geographers structural economic, social and political inequities. Harvey's writings, an important reference for architectural theory, called for a critical position on capitalism and the corporate state. One could suggest that it was only in the aftermath of the 2008 collapse of the financial services firm Lehman Brothers, when economics occupied a central position in the media with austerity measures in all areas of public life, that architecture took a decidedly geographic and political turn towards mapping. New and alternative models of interpretation and new lenses of perception constructed and explored by a cluster of conferences at Toronto and GSD contrasted static spatial programming with ecological and urban processes and evolution. 9 The intellectual framework for the critique of urban design was based on the conceptualization of environments as *soft systems* that were emergent, non-linear and self-organizing (as opposed to the closed, linear and static systems of the *Newtonian* world view). 10 Landscape visualization techniques framed the roles of technology, environment and infrastructure in the built environment. 11 Interest in mapping coincides with increased architectural and urban investigation into infrastructures, ecologies, and systems prompted by landscape urbanism and anticipates more recent exploration of the Deleuzean smooth space of oceans and design studio teaching on city-regions in the tradition of Patrick Geddes and lan McHarg.

As a pedagogical strategy, the potentials of mapping lie not only in the analysis of current territories but also the creation of a project for architecture that includes yet moves beyond critique, engaged as a polemical operation within the design studio to move beyond research to design speculation. It allows the designer to escape know cartographies and allows the invention of others. A drift through the spaces of the imagination in order to arrive at an invention of reality.

\section{Notes}

1. The mathematical sublime concerned things of great size in and of themselves while the dynamically sublime referred to things with a magnitude of force in relation to humans and human will.

2. Edmund Burke, A Philosophical Inquiry into the Origin of our Ideas of the Sublime and the Beautiful (1757), John Boulton, Routledge \& Paul, London, 1958, 136.

3. Immanuel Kant, The Critique of Judgement, trans., J. C. Meredith, Oxford University Press, 1973, 90.

4. Ibid, 106.

5. Bart Lootsma, "Synthetic Regionalization: The Dutch Landscape Toward a Second Modernity," Recovering Landscape: Essays in Contemporary Landscape Architecture, ed., James Corner, Princeton Architectural Press, 1999, 273..
6. Robert Somol and Sarah Whiting, "Notes Around the Doppler Effect and Other Moods of Modernism," Perspecta 33, 2002, 72-77; Reinhold Martin, “Critical of What? Toward a Utopian. Realism," Harvard Design Magazine 22, Spring/Summer 2005, 104-09 and Moment of Truth, Log, No. 7, Winter/Spring 2006, 15-20.

7. Martin (2005), 105.

8. Walter Christaller, Central Places (Die zentralen Orte in Süddeutschland, 1933), cited in Zygmunt Bauman, Globalization: The Human Consequences (1998)

9. Conferences include: Infrastructures: Emerging Practices, Paradigms \& Technologies Reshaping the Contemporary Urban Landscape at University of Toronto, Daniels Faculty of Architecture, Landscape and Design in 2008 and Ecological Urbanism: Alternative and Sustainable Cities of the Future at Harvard GSD in 2009. Also Landscape Infrastructure: Systems \& Strategies for Contemporary Urbanization, Harvard GSD, 2012.

10 Sanford Kwinter, Soft Systems (1993).

11. See Charles Waldheim, Landscape Urbanism Reader (2006) and Landscape as Urbanism (2016); Mohsen Mostafavi, Ecological Urbanism (2010). 